\title{
Pigeon breeder's disease as a cause of hypersensitivity pneumonia in children
}

\author{
Tuğba Ramaslı Gürsoy ${ }^{1 \oplus}$, Zeynep Reyhan Onay ${ }^{1 \oplus}$, Tuğba Şişmanlar Eyüboğlư ${ }^{2 \oplus}$, \\ Ayşe Tana Aslan ${ }^{1}$, Öznur Boyunağa ${ }^{3 \oplus}$ \\ Departments of ${ }^{1}$ Pediatric Pulmonology and ${ }^{3}$ Radiology, Gazi University Faculty of Medicine, Ankara; ${ }^{2}$ Department of Pediatric \\ Pulmonology, Dr Sami Ulus Maternity and Children Research and Training Hospital, Ankara, Turkey.
}

\begin{abstract}
Background and objectives. Hypersensitivity pneumonia is a complex condition due to exposure time, intensity, different clinical presentation, and treatment practices. We aimed to evaluate the patients that were diagnosed with hypersensitivity pneumonia (HSP) due to exposure to pigeons and a review of the literature for diagnosis and treatment of Pigeon Breeder's Disease (PBD) in children.

Method. Between the years of 2009-2018, patients who were diagnosed with HSP due to PBD were included in the study in a pediatric pulmonology department. Findings of our patients, treatments, and prognoses were compared with 17 articles in the literature about PBD in children.

Results. In a 9 year-period, 6 patients were diagnosed as HSP due to PBD. The mean age of the patients was $8.8 \pm 5.4$ years and the average duration of pigeon exposure was $60.1 \pm 6.5$ days. Precipitating antibodies were positive in 3 patients. In four cases, symptoms were resolved with only prevention of pigeon exposure. Two patients who had close contact with pigeons needed oxygen supplementation and steroid therapy.

Conclusion. Hypersensitivity pneumonia should be considered for the differential diagnosis of patients that present with respiratory distress, cough, fever, and weight loss. Prolonged exposure and close contact may worsen the clinical symptoms. In most cases, only exposure prevention is enough, while steroid therapy, oxygen support, and intensive care monitoring may be required in severe cases.
\end{abstract}

Key words: children, hypersensitivity pneumonia, interstitial lung disease, Pigeon Breeder's disease.

Hypersensitivity pneumonia (HSP), also called extrinsic allergic alveolitis, is a non-Ig Emediated immunologic disorder, which develops as a result of repeated inhalation of animal or plant antigens. This typically affects the respiratory tract and pulmonary parenchyma. ${ }^{1}$ HSP was described as "farmer lung" in 1713 in cereal workers by Ramazzani. ${ }^{2}$ The epidemiology of HSP is not definitively known. ${ }^{3}$ Pigeon breeder's

$凶$ Ayşe Tana Aslan

aysetugbapp@gmail.com

Received 28th July 2019, revised 25th September 2019, accepted 22nd October 2019.

This study was presented as poster discussion in the European Respiratory Society (ERS) Congress 15-19 September 2018, Paris, France. disease (6-20\%) and farmer lung (1-19\%) are the most common HSPs. ${ }^{1,3}$

In the pathogenesis of HSP, host sensitivity, immune system, and genetic factors play a role together with antigen exposure. After inhalation of environmental antigens, Th1-mediated type III and IV hypersensitivity reactions are observed in interstitium, alveoli, and the central and terminal airways., ${ }^{4,5}$ Complaints such as cough, dyspnea, chest pain, fever, chills, sweating, weakness, myalgia, and headache can start hours or years after the antigen exposure. ${ }^{5}$ Hypersensitivity pneumonias are defined in three forms as acute, subacute and chronic for clinical course. In acute form, symptoms such as fever, sweating, nausea, headache, muscle pain occur 2-9 hours after exposure and these 
symptoms regress within hours-days. Subacute form symptoms develop slowly in daysweeks, coughing and shortness of breath are prominent. Chronic form shows insidious onset in months, progressive cough and exertional dyspnea, fatigue and weight loss may be the dominant symptoms. ${ }^{6}$

Pigeon breeder's disease (PBD) is one of the most common causes of HSP and is the result of the inhalation of pigeon avian protein antigens. ${ }^{6,7}$ Precipitating antibodies in the serum show exposure and sensitization to pigeon avian protein antigen. ${ }^{8,9}$ In this study, we aimed to evaluate the children that were diagnosed as HSP due to PBD in a pediatric pulmonology department with a review on literature.

\section{Material and Methods}

Between the years of 2009-2018, all patients that were diagnosed as HSP due to PDB were included in the study in a tertiary pediatric pulmonology department. Clinical findings, laboratory and radiological data of patients were noted. Complaints, duration of complaints, contact history, physical examination, laboratory results, pulmonary function test (PFT), chest radiography and thorax CT findings, treatments, and prognosis were recorded. Acute phase reactants of all patients and arterial blood gas results with low oxygen saturation were evaluated. PFT was performed in patients older than 6 years. The presence of precipitating antibody against pigeon avian protein antigen was evaluated in all patients using Ouchterlony plaque method with gel precipitation technique. Thorax CT was performed in patients with auscultation findings on physical examination and infiltration on chest $x$-ray. The presence of ground-glass appearance, mosaic pattern and centrilobular nodules on thorax CT were found to be compatible with HSP.

All available studies about PBD in children from the literature were reviewed. Findings of our patients, treatments, and prognoses were compared to 17 articles in the literature about PBD in children.

Statistical analysis was performed using SPSS v.23.0 program (SPSS Inc., Chicago, IL, USA). The data was expressed as mean and standard deviation. The level of statistical significance was set at p-value of less than 0.05.

This report was performed using the principles of the Declaration of Helsinki and approval was granted by the Gazi University Hospital Ethics Committee (Date: 08/10/2018, Number: 740). Our study is a retrospective archival study. For this type of study formal consent is not required.

\section{Results}

In a 9 year-period, 6 patients were diagnosed as HSP due to PDB. The results of these 6 patients and 71 cases researched from 17 articles in the literature were evaluated.

\section{Clinical features of cases with HSP}

In our six patients, the mean age was $8.8 \pm$ 5.4 years and the average duration of pigeon exposure was $60.1 \pm 6.5$ days. Four of them were female and two were male. All patients' fathers were breeding pigeons as a hobby or for economic reasons. Patients who bred pigeons at home and touched pigeons with their hands were evaluated as close contact. All results of the patients are summarized in Tables I and II. In the family of four patients, there were other patients that were followed up with the diagnosis of HSP due to PBD. All patients admitted with a cough and three patients had a high fever and shortness of breath. The mean duration of complaints was $28.6 \pm 4.3$ days. All cases were evaluated as subacute form. One of the patients was followed up with remission of lymphoma for 6 years and the other five patients had no chronic disease before these complaints. Tachycardia and low oxygen saturation were detected in case 4 and 5. These patients had widespread crackles and weight loss (4\% and $5.5 \%$ ) in the physical examination, case 4 had pulmonary hypertension, and none of them 
Table I. Clinical features of 6 cases with HSP due to pigeon.

\begin{tabular}{|c|c|c|c|c|c|c|}
\hline & Case 1 & Case 2 & Case 3 & Case $4^{*}$ & Case $5^{* \#}$ & Case 6 \\
\hline Age (year) & 2.5 & 2.3 & 9 & 10.5 & 14 & 15 \\
\hline Type of exposure & $\begin{array}{l}\text { Her father } \\
\text { and uncle } \\
\text { were breeding } \\
\text { pigeons at } \\
\text { home. }\end{array}$ & $\begin{array}{l}\text { Her father } \\
\text { and uncle } \\
\text { were breeding } \\
\text { pigeons at } \\
\text { home. }\end{array}$ & $\begin{array}{l}\text { Her father } \\
\text { and uncle } \\
\text { were breeding } \\
\text { pigeons at } \\
\text { home. }\end{array}$ & $\begin{array}{l}\text { Her father } \\
\text { was breeding } \\
\text { pigeons at } \\
\text { home. }\end{array}$ & $\begin{array}{l}\text { His father } \\
\text { was breeding } \\
\text { pigeons near } \\
\text { his home. }\end{array}$ & $\begin{array}{l}\text { His father } \\
\text { and uncle } \\
\text { were breeding } \\
\text { pigeons at } \\
\text { home. }\end{array}$ \\
\hline $\begin{array}{l}\text { Duration of } \\
\text { symptoms (days) }\end{array}$ & & 30 & 30 & 20 & 32 & 30 \\
\hline $\begin{array}{l}\text { Form of } \\
\text { hypersensitivity } \\
\text { pneumonia }\end{array}$ & Subacute & Subacute & Subacute & Subacute & Subacute & Subacute \\
\hline Symptoms & Cough & Cough & $\begin{array}{l}\text { Cough, } \\
\text { shortness of } \\
\text { breath and } \\
\text { high fever. }\end{array}$ & $\begin{array}{l}\text { Cough, } \\
\text { shortness of } \\
\text { breath and } \\
\text { high fever. }\end{array}$ & $\begin{array}{l}\text { Cough, } \\
\text { shortness of } \\
\text { breath and } \\
\text { high fever. }\end{array}$ & Cough \\
\hline $\begin{array}{l}\text { Physical } \\
\text { examination }\end{array}$ & Normal & Normal & Normal & $\begin{array}{l}\text { Tachycardia, } \\
\text { low saturation, } \\
\text { widespread } \\
\text { crackles and } \\
\text { weight loss }\end{array}$ & $\begin{array}{l}\text { Tachycardia, } \\
\text { low saturation, } \\
\text { widespread } \\
\text { crackles and } \\
\text { weight loss }\end{array}$ & Normal \\
\hline
\end{tabular}

* These cases were contacted closely to pigeons (handling pigeons).

* \# This patient was followed up with a diagnosis of remission of lymphoma for 6 years.

had clubbing. The patient was diagnosed with pulmonary hypertension by echocardiography. In cases 4 and 5 , respectively, respiratory rates were 48 and 42 per minute, oxygen saturation were 66 and $82 \%$. Case 4 and 5 that admitted with the findings of severe respiratory distress had longer and more contact with the pigeons than the other patients $(\mathrm{p}>0.05)$.

\section{Laboratory results, PFT, chest $x$-ray and thorax $C T$ findings, treatments and prognosis of cases}

All patients' mean erythrocyte sedimentation rate was $58 \mathrm{~mm} / \mathrm{h}$ and it was high in all patients. The arterial blood gases of cases 4 and 5 with respiratory distress were normal. Three patients had precipitating antibody positivity and two patients could not perform PFT. The PFT was normal in 2 patients and two patients had restrictive pattern in PFT. Patients with a restrictive pattern in PFT results, respectively, $\mathrm{FEV}_{1} 71$ and 68\%; FVC 69 and 62\%; FEV $/$ FVC 102 and 109\% were detected. Bronchodilator reversibility was not performed. Four of our patients had normal chest x-ray and two of them had diffuse interstitial infiltration on chest $x$-ray. The thorax CT was performed in only two patients and bilateral symmetric ground-glass appearance and multiple centrilobular nodules were detected. Other causes such as virus, bacteria including atypical bacteria, vasculitis, immunodeficiency, allergy, rheumatologic and other interstitial lung diseases were excluded. All patients were prevented from contact with the pigeons. Families took the pigeons away from their homes. Families were informed that their homes and clothes should remove the pigeon droppings and other products. Case 4 and 5 were hospitalized for approximately two weeks. Oxygen supplementation and inhaled corticosteroid therapy were given to two patients that were followed-up tachypnea and desaturation that had close contact with pigeons. Despite receiving inhaled corticosteroids, their clinical status did not improve and systemic steroid treatment was started. Pulmonary hypertension regressed in 
Table II. Laboratory results, PFT, chest X-ray and thorax CT findings, treatments and prognosis of cases.

\begin{tabular}{|c|c|c|c|c|c|c|}
\hline & Case 1 & Case 2 & Case 3 & Case 4 & Case 5 & Case 6 \\
\hline $\begin{array}{l}\text { Serum } \\
\text { precipitating } \\
\text { antibodies }\end{array}$ & - & - & + & + & - & + \\
\hline $\begin{array}{l}\text { Pulmonary } \\
\text { function test }\end{array}$ & - & - & Normal & $\begin{array}{l}\text { Restrictive } \\
\text { pattern }\end{array}$ & $\begin{array}{l}\text { Restrictive } \\
\text { pattern }\end{array}$ & Normal \\
\hline $\begin{array}{l}\text { Chest x-ray } \\
\text { and thorax CT } \\
\text { findings }\end{array}$ & Normal & Normal & Normal & $\begin{array}{l}\text { Bilateral } \\
\text { symmetric } \\
\text { ground-glass } \\
\text { appearance } \\
\text { and multiple } \\
\text { centrilobular } \\
\text { nodules }\end{array}$ & $\begin{array}{l}\text { Bilateral } \\
\text { symmetric } \\
\text { ground-glass } \\
\text { appearance } \\
\text { and multiple } \\
\text { centrilobular } \\
\text { nodules }\end{array}$ & Normal \\
\hline Treatments & $\begin{array}{l}\text { Allergen } \\
\text { avoidance }\end{array}$ & $\begin{array}{l}\text { Allergen } \\
\text { avoidance }\end{array}$ & $\begin{array}{l}\text { Allergen } \\
\text { avoidance }\end{array}$ & $\begin{array}{l}\text { Allergen } \\
\text { avoidance } \\
\text { Oxygen } \\
\text { supplementation } \\
\text { Systemic steroids }\end{array}$ & $\begin{array}{l}\text { Allergen } \\
\text { avoidance } \\
\text { Oxygen } \\
\text { supplementation } \\
\text { Systemic steroids }\end{array}$ & $\begin{array}{l}\text { Allergen } \\
\text { avoidance }\end{array}$ \\
\hline Prognosis & $\begin{array}{l}\text { Complaints } \\
\text { regressed at } \\
\text { the first week } \\
\text { follow-up }\end{array}$ & $\begin{array}{l}\text { Complaints } \\
\text { regressed at } \\
\text { the first week } \\
\text { follow-up }\end{array}$ & $\begin{array}{l}\text { Complaints } \\
\text { regressed at } \\
\text { the first week } \\
\text { follow-up }\end{array}$ & $\begin{array}{l}\text { Progressive } \\
\text { clinical and } \\
\text { radiological } \\
\text { improvement }\end{array}$ & $\begin{array}{l}\text { Progressive } \\
\text { clinical and } \\
\text { radiological } \\
\text { improvement }\end{array}$ & $\begin{array}{l}\text { Complaints } \\
\text { regressed at } \\
\text { the first week } \\
\text { follow-up }\end{array}$ \\
\hline
\end{tabular}

control echocardiography without additional treatment in case 4 . In four patients, symptoms were resolved with only prevention of pigeon exposure. Case 4 and 5 showed improvement in chest $\mathrm{x}$-rays and PFTs at follow-up.

\section{Discussion}

Hypersensitivity pneumonia is a complex condition rather than a single disease due to exposure time, intensity, different clinical presentation, and treatment practices. ${ }^{27,28}$ Diagnostic criteria for the diagnosis of HSP have been developed, but none of these criteria have been confirmed. The disease is usually diagnosed by suspicion of contact history and complaints. ${ }^{28,29}$ In differential diagnosis of hypersensitivity pneumonia, viral or bacterial pneumonias, vasculitis, immunodeficiencies, asthma, allergic, rheumatic diseases and other interstitial lung diseases should be investigated and excluded. ${ }^{2,4}$ In cases where laboratory tests and radiological imaging do not benefit, the exposure history may be helpful in the diagnosis.

Pigeon breeder's disease is the most common HSP in children ${ }^{21}$ and it was first described in 1967 by Stiehm et al. ${ }^{10}$ In this study, we evaluated contact histories, physical examination findings, laboratory results, treatments and prognoses of our cases in the light of the literature. Our six patients were reviewed with 71 patients in 17 articles. Case series reporting the PBD are shown in Table III. ${ }^{10-26}$ The literature on PBD was reviewed in detail: The results of 17 articles about pigeon breeder's disease in children and 71 patients were evaluated. The mean age of these patients was $10.1 \pm 0.7$ years. The contact frequency of 32 patients was unknown, while 20 of them had close contacts. The mean duration of complaints was $1.1 \pm 1.8$ years. One of these patients was asymptomatic and the other patients had complaints such as cough, shortness of breath, weight loss, fever, and growth retardation. In these studies, physical examination of 6 patients was normal and the physical examination findings of 32 patients were not given. Other patients had physical 
examination findings such as bilateral crackles, respiratory distress, cyanosis, and clubbing. PFT could not be performed on 15 patients due to age or clinical status, and it was found normal in one case. Obstructive pattern was present in 5 patients, restrictive pattern in 35 patients, and both obstructive and restrictive in 15 patients. Only one of these patients had normal chest x-ray, while interstitial pneumonitis and reticulonodular changes were observed in other cases. In 52 patients, diffuse ground glass appearance and reticulonodular changes were detected on thorax CT. In 64 patients, the precipitating antibody positivity was shown. Bronchoalveolar lavage was performed in 36 patients, it was normal in one patient, it was inconclusive in another patient, and the other patients had lymphocytosis. Lung biopsy was performed in 11 patients and it was found compatible with HSP. Allergen avoidance was applied to all cases except 5 cases. Steroid treatment was given to 59 patients systemically and 5 patients as inhaled.

Breeding pigeons at home and handling pigeons have been considered as close contact. In our patients, two patients with more severe clinical findings (tachypnea, desaturation, respiratory distress, and pulmonary hypertension etc.) were found to be in close contact for a longer time with pigeons. As in our patients, it was observed in the literature that 20 of the patients were in closer contact with the pigeons and their clinical findings were heavier than the others. ${ }^{10-12,14-16}$ In acute cases, cough, shortness of breath, and fever were observed..$^{13,19,25}$ In chronic cases, it was observed that findings such as weight loss and clubbing were added to these findings. ${ }^{12,21,24}$ It is stated that PFTs in PBD could be obstructive, restrictive, or both patterns. . $12-12,17,19-26$ In our two patients, restrictive findings were found in the patients' PFTs.

Chest $x$-ray is normal in $30 \%$ of acute form cases. In our patients, it was observed that patients that have normal chest $x$-ray have normal physical examination findings. In the literature, only one of the 6 patients with normal physical examination findings had normal chest $\mathrm{x}$-ray. ${ }^{10,12,17,18,20}$ Bilateral diffuse homogeneous / heterogeneous areas of opacity and micronodular appearance in the middle and lower zones may occur. In HRCT, ground glass pattern, centrilobular nodules, mosaic pattern, emphysema and honeycombing appearance can be detected. In our patients, as in the literature, bilateral symmetric groundglass appearance and multiple centrilobular nodules were detected in the thorax $\mathrm{CT}$ of two patients with severe respiratory distress. ${ }^{15-18,20-26}$

In the literature, although precipitating antibody positivity was not shown in seven of the 71 patients, antibody positivity was detected only in three of our cases. Physical examination and chest $\mathrm{x}$-ray findings were normal in two cases with antibody positivity in our study. It was observed that in a case with severe respiratory distress findings, precipitating antibody was negative. Similarly, in the literature, although 7 patients had severe respiratory distress, the antibody was negative. ${ }^{18,21,22,26}$ The main reason for this is that tests cannot show some of the responsible antigens. Pigeon breeder's disease was investigated in terms of the antibody, but no valuable information was found about treatment and prognosis.

In the literature, 34 of 36 patients' bronchoalveolar lavage samples had lymphocytosis consistent with HSP. 14,15,18,21,22,25 It was observed that the diagnosis of HSP due to pigeons was made according to contact history, clinical findings, chest x-ray, thorax CT and bronchoalveolar lavage results in patients that were negative for precipitating antibodies. Literature showed that lung biopsy was performed in 11 patients. ${ }^{10,12,18,21,24}$ Lung biopsy can be performed in patients that cannot be diagnosed with clinical, physical examination, laboratory, and radiological findings. In our study, bronchoscopy was not performed in two patients that had severe respiratory distress because of the allergen avoidance and steroid treatment were required to be given rapidly. Parents of other four patients did not give permission for bronchoscopy probably because their clinical findings were mild. Lacasse et 
Table III. Case series reporting the pbreeder's disease in the literature. ${ }^{11-27}$

\begin{tabular}{|c|c|c|c|c|c|c|}
\hline $\begin{array}{l}\text { Authors/ } \\
\text { Year }\end{array}$ & $\mathrm{n}$ & $\begin{array}{l}\text { Average } \\
\text { age } \\
\text { (years) }\end{array}$ & Type of exposure & $\begin{array}{l}\text { Duration of } \\
\text { symptoms }\end{array}$ & Symptoms & Physical examination \\
\hline \multirow[t]{5}{*}{$\begin{array}{l}\text { Stiehm et al } \\
(1967)\end{array}$} & \multirow[t]{5}{*}{5} & \multirow[t]{5}{*}{12.2} & $\begin{array}{l}\text { Case } 1 \text { : He was breeding } 2 \text { pigeons at home } \\
\text { for } 1 \text { month. }\end{array}$ & & \multirow[t]{5}{*}{$\begin{array}{l}\text { Cough, shortness of breath, weight } \\
\text { loss, fever }\end{array}$} & \multirow{5}{*}{$\begin{array}{l}\text { Bilateral crackles (4/5), } \\
\text { hepatosplenomegaly } \\
\text {-Normal (1/5) }\end{array}$} \\
\hline & & & $\begin{array}{l}\text { Case 2: His father was breeding pigeons at } \\
\text { home. }\end{array}$ & 2 years, & & \\
\hline & & & Case 3: He visited the pigeon coop. & Acute onset, & & \\
\hline & & & $\begin{array}{l}\text { Case } 4 \text { : He spent an average of } 6 \text { hours per } \\
\text { day with pigeons for } 3 \text { years. }\end{array}$ & 1 year, & & \\
\hline & & & $\begin{array}{l}\text { Case 5: He raised pigeons for a hobby for } 3 \\
\text { years }\end{array}$ & 6 hours & & \\
\hline $\begin{array}{l}\text { Chandra et } \\
\text { al (1972) }\end{array}$ & 3 & 13 & $\begin{array}{l}\text { Patient's father was breeding pigeons at } \\
\text { home. }\end{array}$ & $\begin{array}{l}6 \text { weeks, } \\
3 \text { weeks, } \\
5 \text { weeks }\end{array}$ & $\begin{array}{l}\text { Cough, shortness of breath, weight } \\
\text { loss }\end{array}$ & $\begin{array}{l}\text { Crackles and respiratory } \\
\text { distress }\end{array}$ \\
\hline $\begin{array}{l}\text { Keith et al } \\
(1981)\end{array}$ & 4 & 15 & $\begin{array}{l}\text { The family moved to a home where pigeons } \\
\text { were kept. }\end{array}$ & 5 years* & $\begin{array}{l}\text { Growth failure, chronic cough, } \\
\text { clubbing, progressive dyspnea, } \\
\text { Asymptomatic }(1 / 4)\end{array}$ & $\begin{array}{l}\text { Moderate clubbing, } \\
\text { bilateral crackles, } \\
\text {-Normal }(1 / 4)\end{array}$ \\
\hline $\begin{array}{l}\text { Tsai et al } \\
\text { (1998) }\end{array}$ & 1 & 7 & $\begin{array}{l}\text { For the past two years, the pigeons had been } \\
\text { living on the same floor as the patient's } \\
\text { bedroom. }\end{array}$ & 2 months & $\begin{array}{l}\text { Dyspnea, anorexia, fever, } \\
\text { nonproductive cough }\end{array}$ & Bilateral basilar crackles \\
\hline \multirow[t]{4}{*}{$\begin{array}{l}\text { Grech et al } \\
(2000)\end{array}$} & \multirow[t]{4}{*}{5} & \multirow[t]{4}{*}{10.8} & $\begin{array}{l}\text { Case 1: He was breeding pigeons at home } \\
\text { Case 2: His father was breeding pigeons at } \\
\text { home. }\end{array}$ & $\begin{array}{l}1 \text { month, } \\
-,\end{array}$ & \multirow[t]{4}{*}{ Cough, shortness of breath } & \multirow[t]{4}{*}{$\begin{array}{l}\text { Bilateral crackles, } \\
\text { wheezing }\end{array}$} \\
\hline & & & $\begin{array}{l}\text { Case 3: His father was breeding pigeons at } \\
\text { home }\end{array}$ & - & & \\
\hline & & & $\begin{array}{l}\text { Case 4: His family were breeding pigeons at } \\
\text { home }\end{array}$ & 5 months, & & \\
\hline & & & Case 5: He visited the pigeon coop. & 10 months & & \\
\hline $\begin{array}{l}\text { F. Ratjen et } \\
\text { al (2002) }\end{array}$ & 9 & 10.7 & - & 3-8 weeks* & Fatigue, cough and dyspnea & - \\
\hline $\begin{array}{l}\text { Yalçın et al } \\
\text { (2003) }\end{array}$ & 1 & 5.5 & $\begin{array}{l}\text { Her father was breeding pigeons at home for } \\
\text { many years. }\end{array}$ & 8 months & $\begin{array}{l}\text { Progressive cough, dyspnea, fever, } \\
\text { lack of appetite }\end{array}$ & $\begin{array}{l}\text { Clubbing, bilateral } \\
\text { crackles }\end{array}$ \\
\hline
\end{tabular}

\begin{tabular}{|c|c|c|c|c|}
\hline \multirow[t]{5}{*}{$\begin{array}{l}\text { Nacar et al } \\
(2004)\end{array}$} & 5 & 11.4 & $\begin{array}{l}\text { Case 1: Her family were breeding pigeons at } \\
\text { home for } 6 \text { months }\end{array}$ & 3 months, \\
\hline & & & $\begin{array}{l}\text { Case 2: His parents were breeding pigeons } \\
\text { at home. }\end{array}$ & 7 years, \\
\hline & & & $\begin{array}{l}\text { Case 3: There was a family history of contact } \\
\text { with neighbours' pigeons. }\end{array}$ & 2 days, \\
\hline & & & $\begin{array}{l}\text { Case } 4 \text { : His father was breeding pigeons at } \\
\text { home for two months. }\end{array}$ & 1 month, \\
\hline & & & $\begin{array}{l}\text { Case } 5 \text { : Her family were breeding pigeons } \\
\text { at home }\end{array}$ & 3 weeks \\
\hline $\begin{array}{l}\text { Ettlin et al } \\
(2005)\end{array}$ & 3 & 5.5 & $\begin{array}{l}\text { Case 1: } 2 \text { weeks holiday on a farm } \\
\text { Case 2: Holiday on a farm } \\
\text { Case 3: Living next to a pigeon house }\end{array}$ & $\begin{array}{l}1.5-2.5 \\
\text { months* }\end{array}$ \\
\hline
\end{tabular}

Nacar et al $1 \quad 13 \quad$ She was in contact with pigeons (2005)

1 month lack of appetite

crackles
Fever, weight loss, cough, shortness Crackles and respiratory of breath, weakness distress, retractions -Normal (1/5)

Dyspnea, weight loss, fatigue, Bilateral crackles fever and mild signs of respiratory -Normal (1/3) distress

Cough, shortness of breath, fever Crackles and respiratory distress

* average duration of symptoms 
Table III. Continued.

\begin{tabular}{|c|c|c|c|c|c|c|}
\hline Chest $x$-ray findings & $\begin{array}{l}\text { Pulmonary } \\
\text { function tests }\end{array}$ & $\begin{array}{l}\text { Serum } \\
\text { precipitating } \\
\text { antibodies }\end{array}$ & Thorax CT findings & BAL & Treatment & Improvement time \\
\hline $\begin{array}{l}\text { Diffuse intersitial } \\
\text { pneumonitis }(4 / 5) \\
\text {-Normal }(1 / 5)\end{array}$ & $\begin{array}{l}\text { Obstructive } \\
\text { pattern }(1 / 4)\end{array}$ & $5 / 5$ & - & - & $\begin{array}{l}\text { Allergen avoidance }(5 / 5) \\
\text { Corticosteroid therapy }(1 / 5)\end{array}$ & $\begin{array}{l}\text { Progressive clinical } \\
\text { and radiological } \\
\text { improvement }\end{array}$ \\
\hline
\end{tabular}

\begin{tabular}{|c|c|c|c|c|c|c|}
\hline $\begin{array}{l}\text { Miliary mottling } \\
\text { throughout both lung fields }\end{array}$ & Normal $(1 / 3)$ &,,+++ & - & - & $\begin{array}{l}\text { Allergen avoidance }(3 / 3) \text {, } \\
\text { corticosteroid therapy }(2 / 3)\end{array}$ & $\begin{array}{l}\text { Progressive clinical } \\
\text { and radiological } \\
\text { improvement }\end{array}$ \\
\hline $\begin{array}{l}\text { Bilateral interstitial } \\
\text { Markings most prominent } \\
\text { in the bases }\end{array}$ & $\begin{array}{l}\text { Restrictive } \\
\text { pattern }\end{array}$ & + & - & - & $\begin{array}{l}\text { Allergen avoidance }(4 / 4) \text {, } \\
\text { corticosteroid therapy }(4 / 4)\end{array}$ & $\begin{array}{l}\text { Complaints regressed in } \\
\text { the follow-up }\end{array}$ \\
\hline $\begin{array}{l}\text { Widespread nodular } \\
\text { interstitial } \\
\text { pattern }\end{array}$ & $\begin{array}{l}\text { Obstructive } \\
\text { and restrictive } \\
\text { pattern }\end{array}$ & + & - & - & Allergen avoidance & 1 month \\
\hline Reticulonodularshadowing & $\begin{array}{l}\text { Restrictive } \\
\text { pattern }\end{array}$ & + & - & $\begin{array}{l}\text { Lymphocytosis+ } \\
(1 / 5)\end{array}$ & $\begin{array}{l}\text { Allergen avoidance }(5 / 5) \text {, } \\
\text { Corticosteroid therapy }(5 / 5)\end{array}$ & $\begin{array}{l}\text { Complaints regressed in } \\
\text { the follow-up }\end{array}$ \\
\hline
\end{tabular}

\begin{tabular}{|c|c|c|c|c|c|c|}
\hline $\begin{array}{l}\text { Diffuse reticular-nodular } \\
\text { changes }\end{array}$ & $\begin{array}{l}\text { Obstructive } \\
\text { and restrictive } \\
\text { pattern }\end{array}$ & + & $\begin{array}{l}\text { Diffuse reticular- } \\
\text { nodular changes }\end{array}$ & $\begin{array}{l}\text { Lymphocytosis +, } \\
\text { CD4/CD8 ratio is } \\
\text { the normal range } \\
(9 / 9)\end{array}$ & $\begin{array}{l}\text { Allergen avoidance }(9 / 9), \\
\text { corticosteroid therapy }(9 / 9)\end{array}$ & $\begin{array}{l}\text { Progressive clinical } \\
\text { and radiological } \\
\text { improvement }\end{array}$ \\
\hline $\begin{array}{l}\text { Bilateral peribronchial } \\
\text { thickening }\end{array}$ & - & + & $\begin{array}{l}\text { Bilateral diffuse } \\
\text { ground-glass } \\
\text { appearance, } \\
\text { disseminated } \\
\text { centrilobuler } \\
\text { densities and air } \\
\text { entrapments in the } \\
\text { lungs }\end{array}$ & - & $\begin{array}{l}\text { Allergen avoidance, } \\
\text { corticosteroid therapy }\end{array}$ & $\begin{array}{l}\text { Progressive clinical } \\
\text { and radiological } \\
\text { improvement }\end{array}$ \\
\hline $\begin{array}{l}\text { Widespread nodular } \\
\text { infiltrates, patchy } \\
\text { infiltration }\end{array}$ & $\begin{array}{l}\text { Obstructive } \\
\text { and restrictive } \\
\text { pattern }(2 / 5)\end{array}$ &,,,,+++++ & $\begin{array}{l}\text { Bilateral } \\
\text { micronodular } \\
\text { infiltrate }\end{array}$ & - & $\begin{array}{l}\text { Allergen avoidance } \\
(5 / 5)(1 / 5 \text { only allergen } \\
\text { avoidance), Systemic } \\
\text { steroids }(3 / 5), \text { Inhaled } \\
\text { steroids }(2 / 5)\end{array}$ & $\begin{array}{l}\text { Complaints regressed in } \\
\text { the follow-up }\end{array}$ \\
\hline $\begin{array}{l}\text { Bilateral micronodular } \\
\text { infiltrate }\end{array}$ & - &,,+-+ & $\begin{array}{l}\text { Diffuse noduler and } \\
\text { patchy infiltration }\end{array}$ & $\begin{array}{l}\text { Lymphocytosis+, } \\
\text { decreased/ } \\
\text { reduced/normal } \\
\text { CD4/CD8 ratios }\end{array}$ & $\begin{array}{l}\text { Allergen avoidance } \\
(3 / 3) \text {, treatment with oral } \\
\text { prednisone }(1-2 \mathrm{mg} / \mathrm{kg} / \\
\text { day) }(3 / 3) \text {, } \\
\text { Inhaled steroids }(3 / 3)\end{array}$ & $\begin{array}{l}9 \text { months, } \\
6 \text { months, } \\
1 \text { year }\end{array}$ \\
\hline $\begin{array}{l}\text { Nodular and patchy } \\
\text { infiltrative appearance in } \\
\text { both lungs }\end{array}$ & $\begin{array}{l}\text { Obstructive } \\
\text { and restrictive } \\
\text { pattern }\end{array}$ & + & - & - & $\begin{array}{l}\text { Allergen avoidance } \\
\text { Systemic steroids } \\
\text { Inhaled steroids }\end{array}$ & $\begin{array}{l}\text { Complaints regressed } \\
\text { in the follow-up ( } 5 \\
\text { months) }\end{array}$ \\
\hline
\end{tabular}


Table III. Continued.

\begin{tabular}{|c|c|c|c|c|c|c|}
\hline $\begin{array}{l}\text { Authors/ } \\
\text { Year }\end{array}$ & $\mathrm{n}$ & Age & Type of exposure & $\begin{array}{l}\text { Duration of } \\
\text { symptoms }\end{array}$ & Symptoms & Physical examination \\
\hline $\begin{array}{l}\text { Ozmen et } \\
\text { al (2013) }\end{array}$ & 4 & 8.5 & $\begin{array}{l}\text { Case 1: His father was breeding pigeons at } \\
\text { home. } \\
\text { Case 2: Pigeons had been bred at home for a } \\
\text { long time. } \\
\text { Case 3: They had been breeding pigeons at } \\
\text { home for } 7 \text { years. } \\
\text { Case } 4 \text { : She was in contact with pigeons for } \\
\text { the last two months }\end{array}$ & $\begin{array}{l}6 \text { months, } \\
2 \text { weeks, } \\
7 \text { years, } \\
2 \text { months }\end{array}$ & $\begin{array}{l}\text { Cough, wheezing, fever and } \\
\text { exercise-induced cough, dyspnea, } \\
\text { sputum production }\end{array}$ & $\begin{array}{l}\text {-Crepitant crackles }(2 / 4) \\
\text { - Normal }(2 / 4)\end{array}$ \\
\hline $\begin{array}{l}\text { Griese et al } \\
\text { (2013) }\end{array}$ & 23 & $\begin{array}{l}9.8 \pm 3 \\
\text { years }\end{array}$ & - & $\begin{array}{l}1.3 \pm 1 \\
\text { months* }\end{array}$ & $\begin{array}{l}\text { Chronic cough, dyspnea, cyanosis, } \\
\text { clubbing, weight loss }\end{array}$ & - \\
\hline
\end{tabular}

Cardoso et 311 Living in a rural area, patients had contact 5 months* al (2014)
Dyspnea, fever, nonproductive cough
Crackles and respiratory distress

$\begin{array}{lllll}\begin{array}{l}\text { Bahçeci- } \\ \text { Erdem S, et } \\ \text { al (2015) }\end{array} & 1 & 9 & \begin{array}{l}\text { He lived above an Office in which birds and } \\ \text { bird manure were merchandised. }\end{array} \\ \begin{array}{l}\text { Tsangla, et } \\ \text { al (2015) }\end{array} & 1 & 12 & \begin{array}{l}\text { They were breeding around } 60 \text { pigeons at } \\ \text { home }\end{array}\end{array}$

Woicka- $\quad 1 \quad 11$

Kolejwa et

al (2017)
Several dozen years ago, the boy's

grandfather had bred 400 pigeons in the attic of the house where the boy lived.
1,5 years
Cough, dyspnea, chest pain

Dry cough, dyspnea and weight loss

\author{
Crackles and respiratory \\ distress \\ Cachexic, dyspneic, \\ tachycardia, tachypnea, \\ use of accessory muscles \\ for respiration, pectus \\ excavatum and bilateral \\ basilar crackles
}

Persistent coughing and shortness Bilateral basilar crackles of breath

$\begin{array}{lllll}\begin{array}{l}\text { Esenboga } \\ \text { et al (2017) }\end{array} & 1 & 16 & \begin{array}{l}\text { Patient was a pigeon fancier and had close } \\ \text { contact for } 5 \text { years (Patient was follow up as as } \\ \text { chronic granulomatous disease) }\end{array} & \begin{array}{l}\text { Since he had } \\ \text { close contact } \\ \text { with pigeons }\end{array}\end{array} \quad \begin{aligned} & \text { Chronic cough and dyspnea } \\ & \text { wistress }\end{aligned}$

\footnotetext{
* average duration of symptoms
} 
Table III. Continued.

\begin{tabular}{|c|c|c|c|c|c|c|}
\hline Chest $x$-ray findings & $\begin{array}{l}\text { Pulmonary } \\
\text { function tests }\end{array}$ & $\begin{array}{l}\text { Serum } \\
\text { precipitating } \\
\text { antibodies }\end{array}$ & Thorax CT findings & BAL & Treatment & Improvement time \\
\hline $\begin{array}{l}\text { Normal-paracardiac- } \\
\text { perihilar involvement }\end{array}$ & $\begin{array}{l}\text { Restrictive } \\
\text { pattern }(3 / 4)\end{array}$ &,,+++ & $\begin{array}{l}\text { Mosaic perfusion, } \\
\text { ground-glass pattern } \\
\text { and centrilobular } \\
\text { micronodules }\end{array}$ & - & $\begin{array}{l}\text { Allergen avoidance } \\
(4 / 4) \text {, inhaled } \\
\text { fluticasonepropionate } \\
\text { treatment }(4 / 4)\end{array}$ & $\begin{array}{l}\text { Complaints regressed in } \\
\text { the follow-up }\end{array}$ \\
\hline
\end{tabular}

\begin{tabular}{|c|c|c|c|c|c|c|}
\hline $\begin{array}{l}\text { Hilar lymph nodes, linear } \\
\text { opacities, reticular } \\
\text { opacities, nodular } \\
\text { opacities, cystic opacities, } \\
\text { bronchiectasis, ground } \\
\text { glass pattern, increased } \\
\text { attenuation consolidation }\end{array}$ & $\begin{array}{l}\text { Restrictive } \\
\text { pattern }(22 / 23)\end{array}$ & $+(21$ of 23$)$ & $\begin{array}{l}\text { Hilar lymph nodes } \\
\text { linear opacities } \\
\text { reticular opacities } \\
\text { nodular opacities } \\
\text { bronchiectasis } \\
\text { ground glass pattern, } \\
\text { increased attenuation }\end{array}$ & $\begin{array}{l}\text { Done in } 17 \\
\text { children } \\
\text { lymphocytosis +, } \\
\text { CD4/CD8 ratio is } \\
\text { elevated. }\end{array}$ & $\begin{array}{l}\text { Allergen avoidance (18 } \\
\text { of } 23 \text { ) } \\
\text { Systemic steroids ( } 20 \text { of } 23 \text { ) } \\
\text { Inhaled steroids ( } 11 \text { of } 23 \text { ) }\end{array}$ & $\begin{array}{l}17 \text { healthy } \\
5 \text { improved } \\
1 \text { worse }\end{array}$ \\
\hline $\begin{array}{l}\text { Bilateral diffuse perihilar } \\
\text { interstitial infiltrate }\end{array}$ & $\begin{array}{l}\text { Obstructive } \\
\text { pattern }\end{array}$ & - & $\begin{array}{l}\text { Parenchymal } \\
\text { thickening in both } \\
\text { lungs, small nodules } \\
\text { with ill-defined } \\
\text { borders, and ground- } \\
\text { glass changes }\end{array}$ & $\begin{array}{l}\text { Lymphocytosis +, } \\
\text { CD4/CD8 ratio is } \\
\text { decreased }\end{array}$ & $\begin{array}{l}\text { Allergen avoidance }(3 / 3) \\
\text { Systemic steroids }(2 / 3) \\
\text { Inhaled steroids }(3 / 3)\end{array}$ & $\begin{array}{l}\text { Progressive clinical } \\
\text { and radiological } \\
\text { improvement }\end{array}$ \\
\hline Patchy noduler infiltration & $\begin{array}{l}\text { Obstructive } \\
\text { pattern }\end{array}$ & + & $\begin{array}{l}\text { Ground glass areas } \\
\text { in both lungs }\end{array}$ & - & $\begin{array}{l}\text { Allergen avoidance } \\
\text { Systemic steroids }\end{array}$ & $\begin{array}{l}\text { Progressive clinical } \\
\text { and radiological } \\
\text { improvement }\end{array}$ \\
\hline $\begin{array}{l}\text { Bilateral ground glass } \\
\text { pattern }\end{array}$ & $\begin{array}{l}\text { Restrictive } \\
\text { pattern }\end{array}$ & + & $\begin{array}{l}\text { Diffuse mosaic } \\
\text { pattern and } \\
\text { multiple ill-defined } \\
\text { centrilobular nodular } \\
\text { lesions in both upper } \\
\text { lobes and interstitial } \\
\text { thickening in the } \\
\text { apical segment of left } \\
\text { lower lobe. }\end{array}$ & Inconclusive & $\begin{array}{l}\text { Allergen avoidance } \\
\text { Oxygen supplementation } \\
\text { Corticosteroid therapy } \\
\text { Inhaled budesonide }\end{array}$ & $\begin{array}{l}\text { Complaints regressed in } \\
\text { the follow-up }\end{array}$ \\
\hline $\begin{array}{l}\text { Bad aeration and } \\
\text { parenchymal- interstitial } \\
\text { lesions with atypical } \\
\text { changes in the hilar }\end{array}$ & $\begin{array}{l}\text { Obstructive } \\
\text { and restrictive } \\
\text { pattern }\end{array}$ & + & $\begin{array}{l}\text { Interlobular nodules } \\
\text { in both the lungs, } \\
\text { ground glass pattern }\end{array}$ & $\begin{array}{l}\text { Reduced level } \\
\text { of macrophages } \\
(57 \%) \text { and } \\
\text { increased } \\
\text { percentages of } \\
\text { neutrophils ( } 31 \%) \\
\text { and eosinophils } \\
(6 \%) \text { with } 6 \% \text { of } \\
\text { lymphocytes. }\end{array}$ & $\begin{array}{l}\text { Allergen avoidance, } \\
\text { methylprednisolone } 2 \mathrm{mg} / \\
\mathrm{kg} / \text { day up to a maximum of } \\
60 \mathrm{mg} / \text { day }\end{array}$ & $\begin{array}{l}\text { Improved and } \\
\text { auscultatory changes } \\
\text { resolved. }\end{array}$ \\
\hline $\begin{array}{l}\text { Pathcy ground glass } \\
\text { appearance with fine }\end{array}$ & $\begin{array}{l}\text { Obstructive } \\
\text { and restrictive } \\
\text { pattern }\end{array}$ & - & $\begin{array}{l}\text { Patchy, vaguely } \\
\text { centrilobular ground- } \\
\text { glass opacification } \\
\text { with air trapping } \\
\text { areas, interlobular } \\
\text { septal thickening and } \\
\text { subpleural bullae }\end{array}$ & Normal & $\begin{array}{l}\text { Allergen avoidance, } \\
\text { Oxygen supplementation }\end{array}$ & $\begin{array}{l}\text { Complaints regressed in } \\
\text { the follow-up }\end{array}$ \\
\hline
\end{tabular}


al. ${ }^{6}$ showed that appropriate cases could be diagnosed as HSP with history, clinical, physical examination findings and simple laboratory tests without the need for invasive procedures such as bronchoalveolar lavage and biopsy.

The most important factor in treatment is the removal of the antigen. Systemic or inhaled corticosteroid therapy has been used in cases with respiratory insufficiency. In the acute form, prognosis has usually been good and often the symptoms are reduced with the prevention of exposure. Fibrosis development determines prognosis in subacute and chronic forms. ${ }^{27-30}$

In our patients, four patients were treated only with pigeon exposure prevention. In the literature, allergen avoidance was not performed in 5 patients for social reasons and 7 patients were treated only by allergen avoidance. ${ }^{10,11,13}$ It was observed that these patients were admitted with findings such as cough and fever without respiratory complaints and that thorax CT was not required because of the mild clinical and physical examination findings. Systemic steroids were used in the treatment of patients with respiratory failure, desaturation, ground glass appearance, and reticulonodular changes on thorax $\mathrm{CT}$. In the literature, 5 patients were treated only with inhaled steroids and 59 patients with systemic steroids. It was shown that patients with severe clinical, physical examination, and thorax CT findings needed steroid treatment. In all cases in the literature, as in our patients, it was observed that the clinical findings regressed in the follow-up with avoidance of allergen, inhaled, or systemic steroid therapy. ${ }^{10-26}$ In the literature, a patient with chronic granulomatous disease was given steroid treatment as well as hydroxychloroquine treatment. ${ }^{26}$

In conclusion, HSP should be considered in the differential diagnosis of patients that present with respiratory distress, cough, fever, and weight loss. Detailed contact history should be questioned. Close and long-term pigeon contact can lead to severe clinical findings. Serum precipitating antibodies may not be present in every patient and do not give information about treatment and prognosis. Radiological diagnosis may be helpful for diagnosis. Patients with mild clinical and radiological findings may be treated with pigeon exposure prevention, while steroid treatment, oxygen support, and intensive care follow-up may be necessary in severe cases.

\section{Acknowledgement}

All authors declare no conflict of interest. All authors approved the final manuscript as submitted and agree to be accountable for all aspects of the work.

\section{REFERENCES}

1. Costabel U, Guman J. Less common diseases: hypersensitivity pneumonitis. In: Baugman RP, du Bois RM, Lynch JP, Wells AU (eds). Diffuse Lung Disease. A Practical Approach (1st ed). London: Hodder Arnold Publication, 2004: 203-212.

2. Dhar S, Daroowalla F. Hypersensitivity pneumonitis. Clin Pulm Med 2011; 18: 169-174.

3. Lopez M, Salvaggio JE. Epidemiology of hypersensitivity pneumonitis/allergic alveolitis. Monogr Allergy 1987; 21: 70-86.

4. Selman M, Pardo A, King TE Jr. Hypersensitivity pneumonitis: insights in diagnosis and pathobiology. Am J Respir Crit Care Med 2012; 186: 314-324.

5. Agostini C, Trentin L, Facco M, Semenzato G. New aspects of hypersensitivity pneumonitis. Curr Opin Pulm Med 2004; 10: 378-382.

6. Lacasse Y, Selman M, Costabel U et al; HP Study Group. Clinical diagnosis of hypersensitivity pneumonitis. Am J Respir Crit Care Med 2003; 168: 952-958.

7. Bertorelli G, Bocchino V, Olivieri D. Hypersensitivity pneumonitis. Eur Respir Mon 2000; 14: 120-136.

8. Rose CS. Hypersensitivity pneumonitis. In: Murray JF, Nadel JA (eds). Textbook of Respiratory Medicine (3rd ed). Philadelphia: WB Saunders Company, 2000: 1867-1884.

9. Fenoglio CM, Reboux G, Sudre B, et al. Diagnostic value of serum precipitins to mould antigens in active hypersensitivity pneumonitis. Eur Respir J 2000; 29: 706-712.

10. Stiehm ER, Reed CE, Tooley WH. Pigeon breeder's lung in children. Pediatrics 1967; 39: 904-915. 
11. Chandra S, Jones HE. Pigeon fancier's lung in children. Arch Dis Child 1972; 47: 716-718.

12. Keith HH, Holsclaw DS Jr, Dunsky EH. Pigeon breeder's disease in children: a family study. Chest 1981; 79: 107-110.

13. Tsai E, Couture D, Hughes DM. A pediatric case of pigeon breeder's disease in Nova Scotia. Can Respir J 1998; 5: 507-510.

14. Grech V, Vella C, Lenicker H. Pigeon breeder's lung in childhood: varied clinical picture at presentation. Pediatr Pulmonol 2000; 30: 145-148.

15. Ratjen F, Bredendiek R, Zheng L, Brendel M, Costabel U. Lymphocyte subsets in bronchoalveolar lavage fluid of children without bronchopulmonary disease. Am J Respir Crit Care Med 1995; 152: 174178.

16. Yalçın E, Kiper N, Göçmen A, Ozçelik U, Doğru D, Misirligil Z. Pigeon-breeder's disease in a child with selective Ig A deficiency. Pediatr Int 2003; 45: 216218.

17. Nacar N, Kiper N, Yalcin E, et al. Hypersensitivity pneumonitis in children: pigeon breeder's disease. Ann Trop Paediatr 2004; 24: 349-355.

18. Stauffer Ettlin M, Pache JC, Renevey F, HanquinetGinter S, Guinand S, Barazzone Argiroffo C. Bird breeder's disease: a rare diagnosis in young children. Eur J Pediatr 2006; 165: 55-61.

19. Nacar N, Kiper N, Doğru D, Özçelik U, Özön A, Cobanoğlu N. Güvercin besleyenlerin pnömonisi olan bir çocukta inhale steroid tedavisi. Çocuk Sağlığı ve Hastalıkları Dergisi 2005; 48: 330-333.

20. Özmen S, Doğru M, Duman H, Mısırlıŏ̆lu ED, Giniş T, Bostanci İ. Bird fancier's lung disease: a single center experience. Turk Arch Ped 2013; 48: 327-331.

21. Griese M, Haug M, Hartl D, Teusch V, GlöcknerPagel J, Brasch F; National EAA Study Group. Hypersensitivity pneumonitis: lessons for diagnosis and treatment of a rare entity in children. Orphanet J Rare Dis 2013; 8: 121.
22. Cardoso J, Carvalho I. The value of family history in the diagnosis of hypersensitivity pneumonitis in children. J Bras Pneumol 2014; 40: 183-187.

23. Bahçeci-Erdem S, Nacaroğlu HT, Ünsal-Karkıner CŞ, et al. Hypersensitivity pneumonia in a school child admitted to the hospital's asthma clinic. Turk J Pediatr 2015; 57: 529-532.

24. Tsanglao WR, Nandan D, Chandelia S, Bhardwaj M. Chronic hypersensitivity pneumonia due to Pigeon breeders disease. Indian Pediatr 2017; 54: 55-57.

25. Woicka-Kolejwa K, Mazurek H, PawlowskaIwanicka K, Stelmach I. Hypersensitivity pneumonitis in an 11-year-old boy-a case report. Pediatr Allergy Immunol Pulmonol 2017; 30: 60-63.

26. Esenboga S, Emiralioglu N, Cagdas N, et al. Diagnosis of interstitial lung disease caused by possible hypersensitivity pneumonitis in a child: think CGD. J Clin Immunol 2017; 37: 269-272.

27. Okamoto T, Fujii M, Furusawa H, Tsuchiya K, Miyazaki Y, Inase N. The usefulness of KL-6 and SP-D for the diagnosis and management of chronic hypersensitivity pneumonitis. Respir Med 2015; 109: 1576-1581.

28. Riario Sforza GG, Marinou A. Hypersensitivity pneumonitis: a complex lung disease. Clin Mol Allergy 2017; 15: 6.

29. Schuyler M, Cormier Y. The diagnosis of hypersensitivity pneumonitis. Chest 1997; 111: 534536.

30. Stop exogenous allergic alveolitis (EAA) in childhood: healthy into adulthood-a randomized, double-blind, placebo-controlled, parallel-group study to evaluate prednisolone treatment and course of disease. https://www.clinicaltrialsregister.eu/ ctr-search/trial/2013-003689-15/DE. Eudra CT: 2013003689-15. IZKS trialcode: 2013-007 Final Version 2.0 Date 24.09.2014. 